\title{
Determinants of agricultural intensification and maize productivity in the Maya Biosphere Reserve, Guatemala
}

\author{
AMY M. LERNER, DAVID LÓPEZ-CARR \\ University of California, Santa Barbara, Department of Geography
}

\begin{abstract}
Tropical deforestation is one of the world's most pressing environmental issues. Some theorists, building on agricultural economist Esther Boserup's work, propose that agricultural intensification through population growth curbs deforestation through limiting extensive forest cutting for agricultural purposes. Although various scholars have studied the drivers of tropical deforestation, few have examined the determinants of agricultural intensification, which plays key role in forest conservation. This paper uses household data collected in the Maya Biosphere Reserve, Guatemala, to uncover predictor variables associated with intensification in farmed plots. Maize productivity is statistically and positively related with several key variables including smaller farms, and a small percentage of overall land area in crops; the latter households dedicate more of their output to market sales instead of subsistence. These results challenge the applicability of Boserup's theory to the tropical agricultural frontier but is consistent with theories of land and labor maximization.
\end{abstract}

Key words: Deforestation, intensification, land use, Guatemala, Petén

\section{Introduction}

Tropical deforestation has received a great deal of attention particularly because of its relation to biodiversity loss, reducing the global carbon sink, and increased soil erosion (Carr et al. 2009). Agricultural frontiers, as in the northern departamento (state) of Petén in Guatemala, constitute a critical forested area at risk to deforestation by smallholder farming activities. It is therefore critical to manage the protected forest in these areas for human-use in addition to promoting forest conservation (Sundberg 1998). Agricultural intensification is proposed by some theorists as a way to reduce forest clearing by increasing the output in farmed plots, or increasing efficiency instead of cutting more forest (Boserup 1965).

Brush and Turner II's model of "modified consumption" constitutes a more formal modification of Boserup's theory. Brush and Turner II (1987) proposed that demand for agricultural intensity should be expanded to include biological, social, and market 
forces. Social variables such as kinship, culture, and taxes were thus posited as potential demands over and above population pressure (Brush and Turner II 1987). Further, intensification responses, such as the use of technologies and petrochemicals, were considered alternative intensification responses to fallow compaction (Behrens et al. 1994; Bilsborrow and Geores 1994; Connelly 1994).

Since Brush and Turner II's 1987 work, research indicated the importance of diverse spatial and temporal intensification responses, including the use of irrigation, farm machinery and agro-chemicals (Zimmerer 1991; Netting, Stone et al. 1993; Behrens, Baksh et al. 1994; Bilsborrow and Geores 1994; Connelly 1994; Krautkraemer 1994; Schelhas 1996; Turner II and Ali 1996; Ahmed and Sanders 1998; Shriar 2000). Yet most research on farmer responses to changing demographic conditions continues to neglect other non-agricultural responses (e.g., fertility modification, migration, and off-farm employment). Geertz demonstrated how in population dense areas of Indonesia, excess labor was absorbed through "involution" by means of double cropping, careful weeding, etc. (Geertz 1968). This model is appropriate for rural areas of high population density such as Southeast Asia and parts of sub-Saharan Africa.

The body of research on agricultural intensification generally presumes that the demand from population density or markets is often insufficient to compel frontier migrants to intensify their agriculture (Carr 2004; Carr et al. 2006; DeSherbinin et al. 2007). In environments of abundant (but insecure) resource access and scarce labor (e.g., in an agricultural frontier), most forms of intensification represent an unnecessary labor burden, uneconomical, inefficient, or too risky for small, semi-subsistence producers (Feder and Onchan 1987). Fragile and informal terms of occupancy may further discourage intensification since rapid and widespread forest clearing signal de facto occupancy, rebuffing the intentions of potential squatters (e.g., Feder and Onchan 1987; Schmink and Wood 1993; Schneider 1993; Kaimowitz 1995; Clark 1996). Alternatively, despite a large land to labor ratio, if market penetration is sufficient, opportunities may exist for settlers with reasonable access to those markets to induce intensification if production under current land management fails to meet market demand (e.g., Brush and Turner II 1987; Goldman 1993; Shriar 2000). Thus, in a frontier environment, population growth is more likely to induce agricultural extensification whenever land is sufficient (Boserup 1981).

Carr (2008a) has examined determinants of migration to the Sierra de Lacandon National Park (SLNP) and drivers of deforestation in following settlement in the SLNP (Carr 2005; 2008b). What remains to be researched are potential determinants of agricultural intensification. We attempt here to uncover correlations between socioeconomic, demographic and environmental variables and agricultural intensification. The results of the findings may inform direct management strategies for the vulnerable protected areas in the National Park. 


\section{Methods}

Data Description

Carr (2005) collected demographic, socio-economic, and land-use data through 241 household interviews in 8 communities within the Sierra de Lacandon National Park in the department of Petén, Guatemala (see Figure 1) during 1998-1999. Similarly, Shriar (2001) utilized a range of variables in predicting agricultural intensification in another region of the Petén that helped inform our choice of variables in this regression analysis (Shriar 2001; Carr 2005). Intensification is often measured by the actual agricultural methods, such as using fertilizer or number of years successively cropped, but for the purposes of this analysis we used the amount of maize (in quintales) produced per hectare, which symbolizes overall efficiency, as our response variable.

The independent variables we examine are the following: household variables (family size, population density, number of years on the land and ethnicity) and agricultural variables (percent of land in crops (versus forest or pasture), farm size, methods intensity, and percent of the maize produced that is sold to market (a subsistence measure). Although there were originally 241 data points, we deleted all points with zero values in the response variable, meaning that they do not produce maize. This reduced the data points to 225 values.

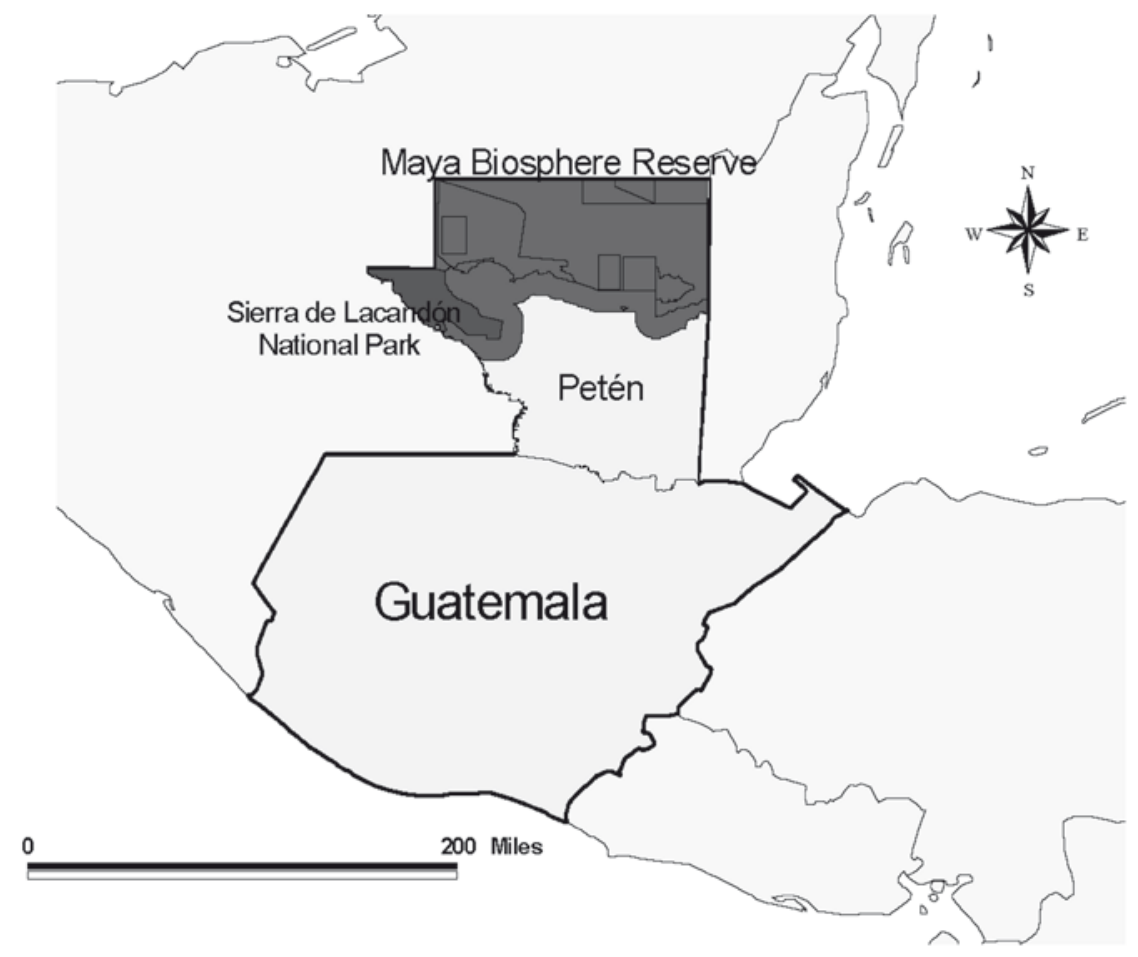

Fig. 1 Area of interest 


\section{Data Diagnostics}

We ran standard diagnostics on all predictor variables. Normal probability plots of the studentized and r-student residuals showed slight deviation at the tails, suggesting possible outliers or a non-linear distribution. We removed each outlier and re-ran the model; the adjusted r-squared value remained the same or decreased. Therefore we retained all observations. We created a histogram and normal probability plot to look at the distribution of our response variable, quintales of maize produced per hectare. The normal probability plot showed that a square-root transform might better the distribution. We transformed the variable with more parsimonious results (Figures 2 and 3). Therefore, all results incorporate the square-root transform of our dependent variable. There is already a potential outlier in the data, as seen on figures 2 and 3 , that represents one very efficient farm with high productivity. We left it in the data to see how it performed in the diagnostic tests.

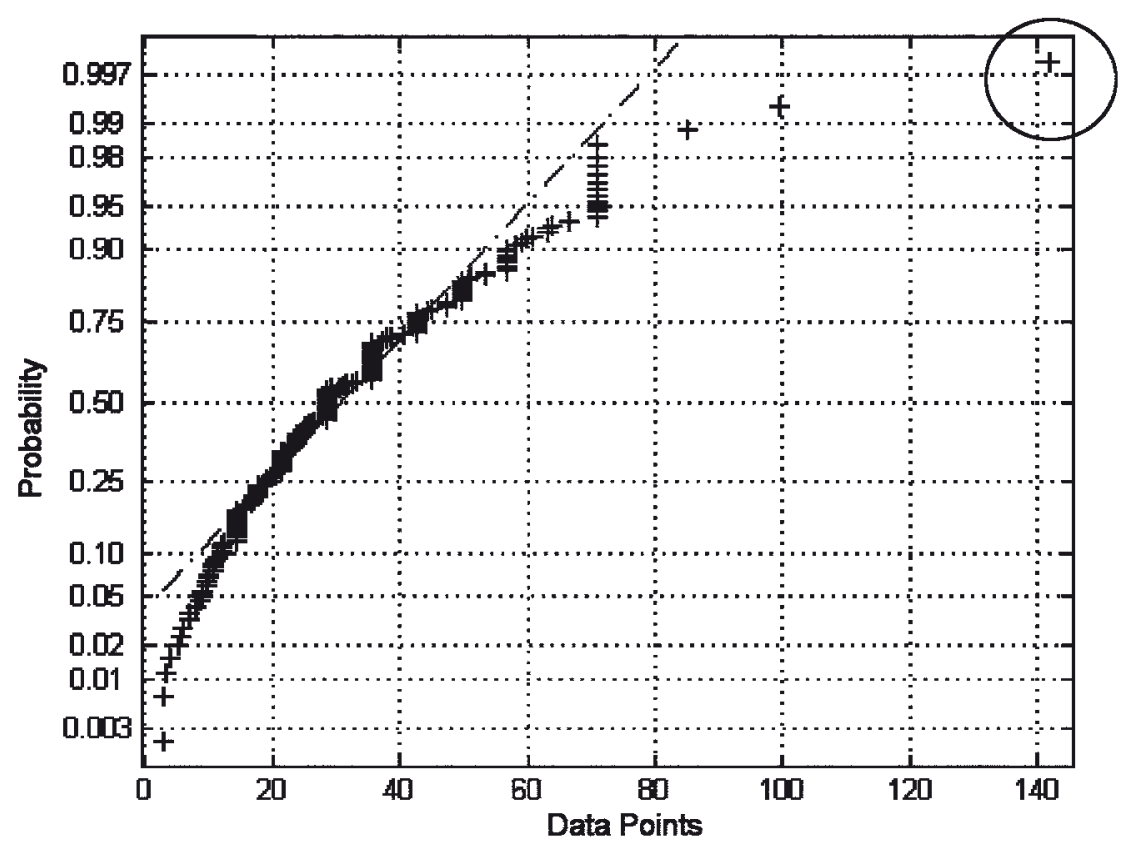

Fig. 2 Normal Probability Plot of Maize Production

We also began with ethnicity as a categorical variable but when it was incorporated into the model the results were much less significant. This might be due to most farmers belonging to one of the three categories of ethnicity, therefore minimizing variability across ethnic categories (ladino, indigenous, other). We began our model, therefore, with six continuous predictor variables: duration on the farm, size of farm, family size, amount of maize sold (subsistence), percent of farm in crops, and intensity rank. 


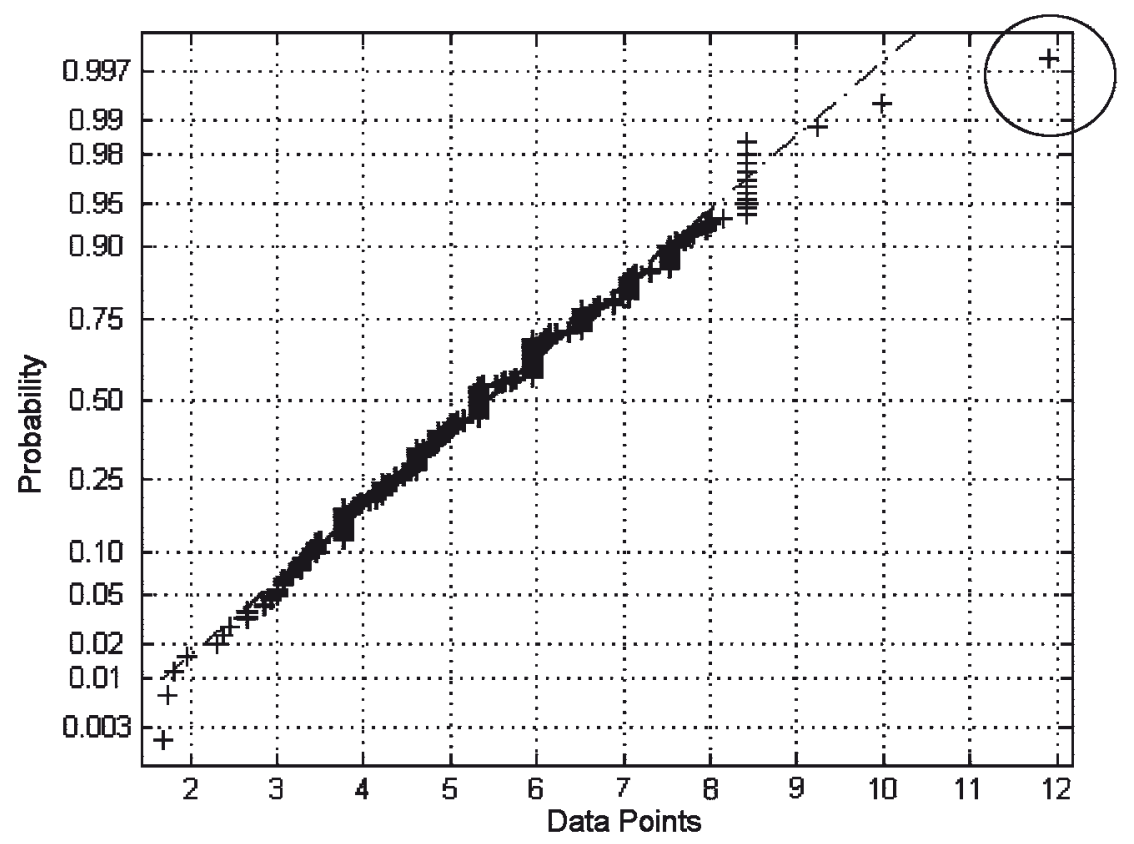

Fig. 3 Normal Probability Plot of Maize Production, Transformed

\section{Results}

The initial results of the model are found in the table below:

Table 1 Model 1 - Multiple Regression, Agricultural Intensification

\begin{tabular}{|l|c|c|c|c|}
\hline & B & Std Error & t-value & p-value \\
\hline Intercept & 3.623 & 0.538 & 6.731 & 0 \\
\hline Duration on Farm & 0.025 & 0.018 & 1.416 & 0.158 \\
\hline Farm Size & -0.026 & 0.007 & -4.064 & 0 \\
\hline \% Maize Sold & 3.249 & 0.434 & 7.486 & 0 \\
\hline \% Farm in Crops & -1.527 & 0.429 & -3.561 & 0 \\
\hline Household Size & 0.050 & 0.034 & 1.485 & 0.139 \\
\hline Intensity Index & 0.032 & 0.076 & 0.425 & 0.671 \\
\hline adj r-squared & 0.215 & & & \\
\hline F-statistic & 11.242 & & & \\
\hline p-value & 0 & & & \\
\hline MSE & 2.136 & & & \\
\hline
\end{tabular}


We expected three variables that according to background would have theoretical relations with corn production: household size, intensity index, and duration on farm. Their p-values were insignificant. We removed these three variables independently, with various combinations, and model fit improved. The final model is therefore:

$$
Y=\beta_{0}+\beta_{1} X_{1}+\beta_{2} X_{2}+\beta_{3} X_{3}
$$

where $\mathrm{Y}$ is the response variable maize productivity, $\mathrm{X}_{1}=$ farm size; $\mathrm{X}_{2}=$ percent maize sold to market (subsistence value); and $\mathrm{X}_{3}=$ percent of farm in crops. The results of this model are found in table 2 below.

Table 2 Model 2 - Multiple Regression, Agricultural Intensification

\begin{tabular}{|l|c|c|c|c|}
\hline & B & Std Error & t-value & p-value \\
\hline Intercept & 4.142 & 0.460 & 8.994 & 0 \\
\hline Farm Size & -0.022 & 0.006 & -3.517 & 0.001 \\
\hline$\%$ Maize Sold & 3.165 & 0.433 & 7.303 & 0 \\
\hline \% Farm in Crops & -1.372 & 0.424 & -3.235 & 0.001 \\
\hline Multiple r-squared & 0.218 & & & \\
\hline F-statistic & 20.519 & & & \\
\hline P-value & 0 & & & \\
\hline MSE & 2.158 & & & \\
\hline
\end{tabular}

The plot of fitted values versus the residuals is below and demonstrates a reasonable linear fit of the model (Figure 4). We calculated the regression between the fitted and residual values and there was no significant correlation, with a slope of zero, which supports this relationship as linear.

By creating partial regression plots, we examined how each of the three variables contributes to the overall model. Figures 5, 6, and 7 show that none of the predictor variables has a very strong relationship but there are significant trends. Farm size controlling for the other two predictors is shown in figure 5, revealing that as farm size increases, productivity per hectare decreases. Also, as more output is sold to market, and a farm is less reliant on subsistence production, productivity increases (Figure 6).

Figure 7 indicates that productivity becomes higher with decreasing crop area, meaning that farmers need to be as efficient as possible with available land in crop production. 


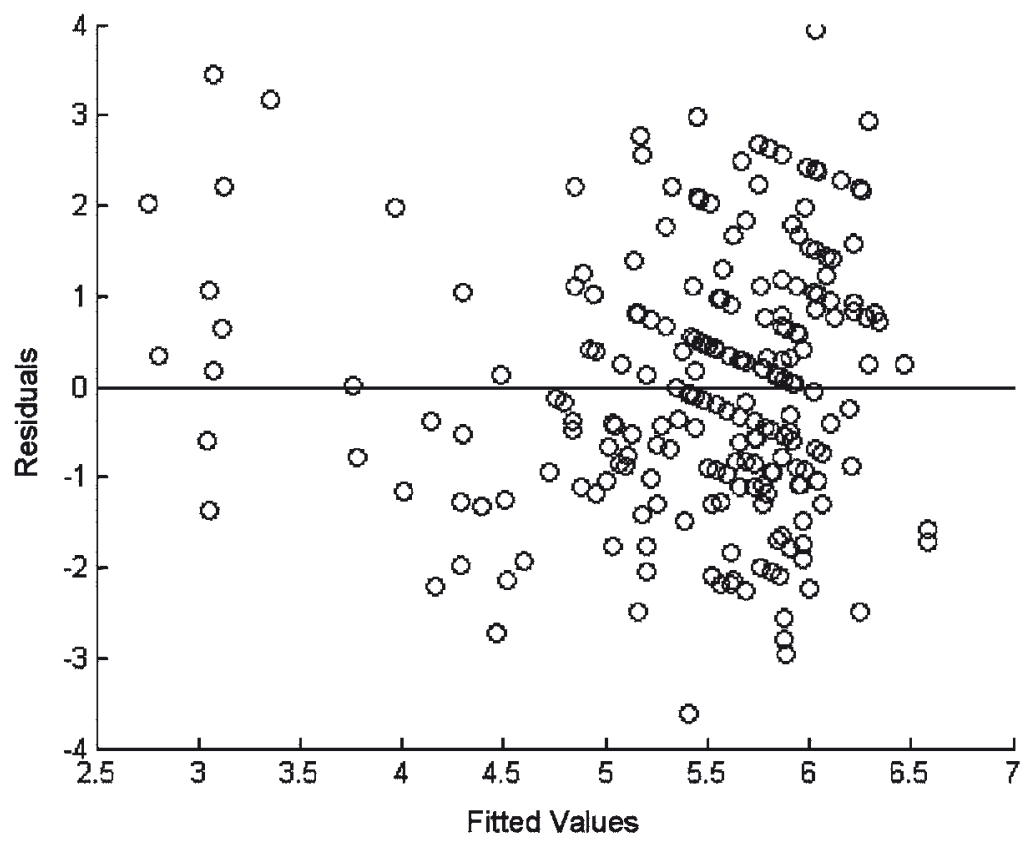

Fig. 4 Fitted Values vs. Residuals

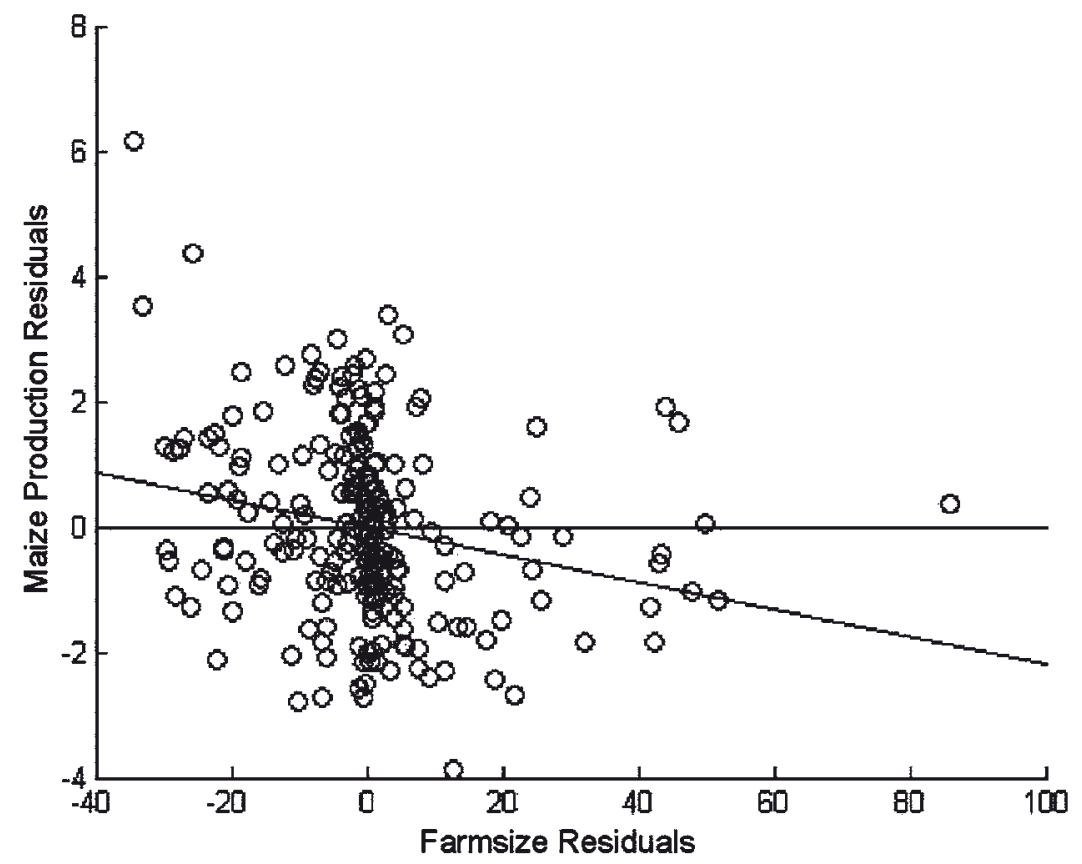

Fig. 5 Farmsize vs. Maize Production Controlling for Percent Farm in Crops and Subsistence 


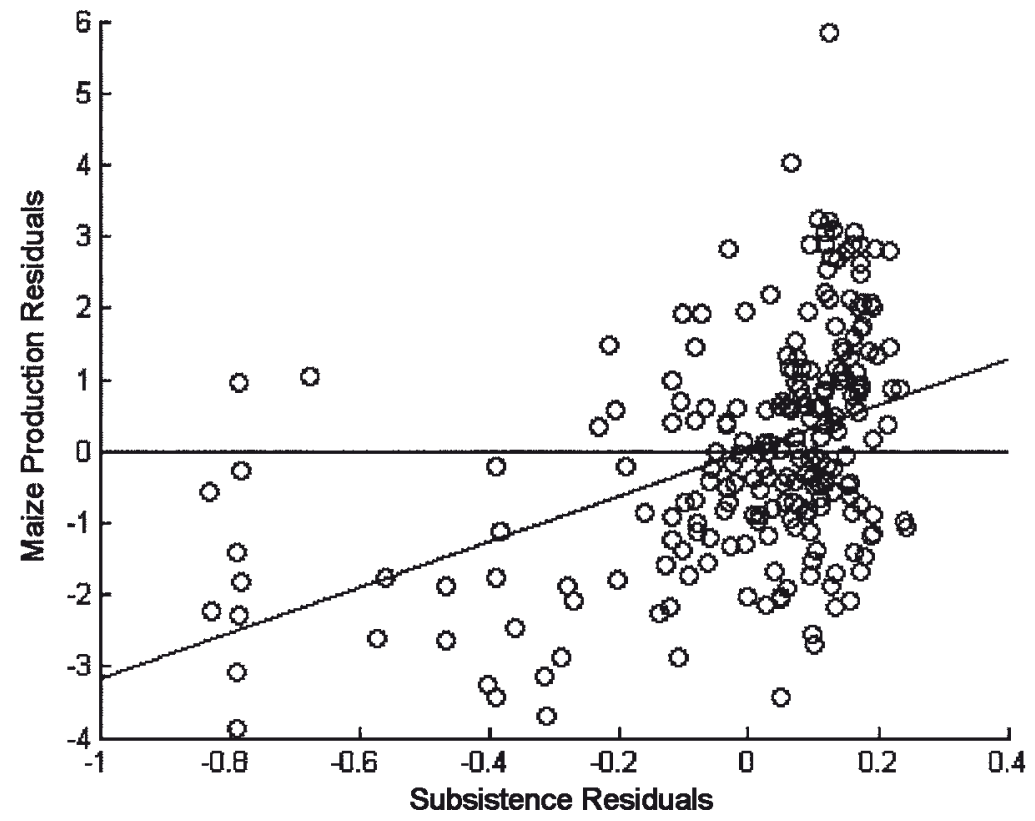

Fig. 6 Subsistence vs. Maize Production Controlling for Percent Farm in Crops and Farm Size

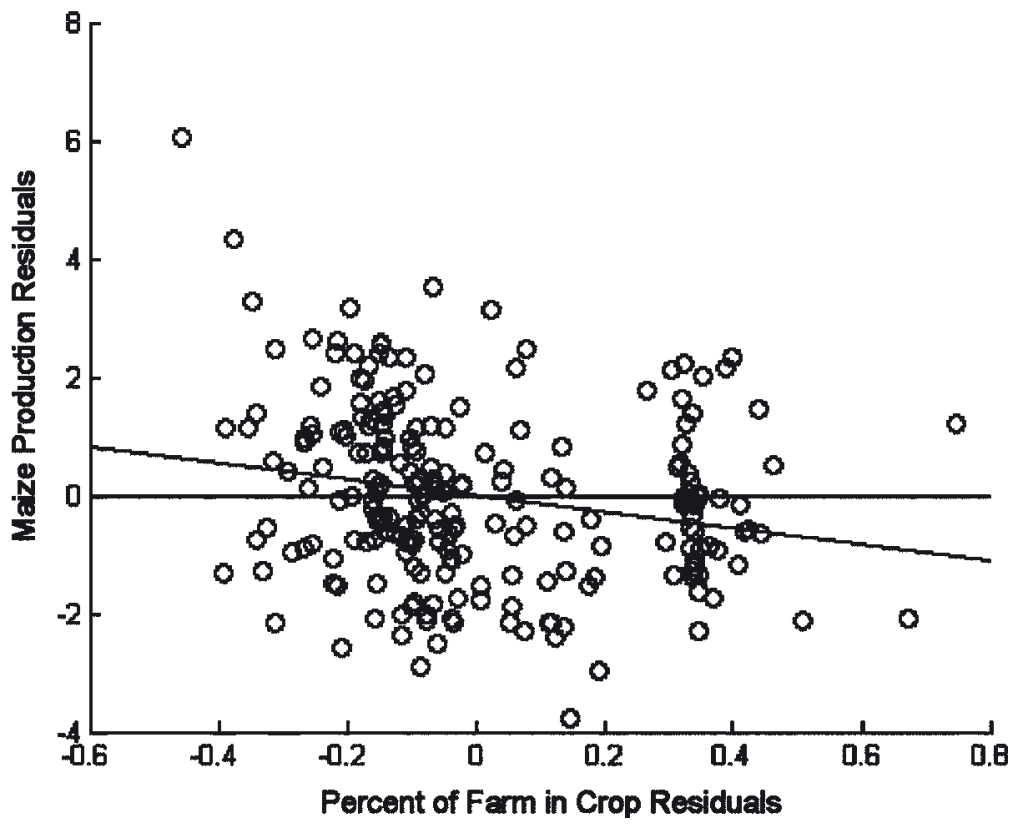

Fig. 7 Percent of Farm in Crop vs. Maize Production Controlling for Subsistence and Farm Size 


\section{Conclusion}

The model shows that there is a correlation between high productivity of maize per hectare and smaller farm size, decreased subsistence level (more maize sold to market), and less percentage of the farm in crops. In other words, small farms with a small amount of land in crops devoting their crop for market sales are the most productive. This finding is consistent with theories of land and labor maximization. The results challenge the applicability of Boserupian theory to agricultural frontiers. Household size and length of time on the farm were insignificant predictors of maize production intensification. We believe that this is because land availability is too great and population density and labor and capital inputs are too low for population induced intensification. Future research would fruitfully pursue the question: At what threshold of population density is intensification inevitable?

\section{References}

AHMED, M. M., SANDERS, J. H. (1998): Shifting from extensive to intensive agricultural systems: A case study in the Sudan Agricultural Systems 58(2), pp. 253-68.

BEHRENS, C. A., BAKSH, M. G. ET AL. (1994): A regional analysis of Bari land use intensification and its impact on landscape heterogeneity. Human Ecology 22(3), pp. 279-316.

BILSBORROW, R. E., GEORES, M. (1994): Population Change and Agricultural Intensification in Developing Countries. Population and Environment: Rethinking the Debate. L. Arizpe, M. P. Stone and D. C. Major. Oxford, Westview Press.

BOSERUP, E. (1965): The conditions of agricultural growth; the economics of agrarian change under population pressure. Chicago, Aldine Pub. Co.

BOSERUP, E. (1981): Population and technological change: A study of long-term trends. Chicago, University of Chicago Press.

BRUSH, S. B., TURNER, II B. (1987): The nature of farming systems and views of their change. Comparative Farming Systems. B. Turner II and S. B. Brush. New York, The Guilford Press.

CARR, D. L. (2004): Proximate population factors and deforestation in tropical agricultural frontiers. Population and Environment, 25(6), pp. 585-612.

CARR, D. L. (2005): Population, land use, and deforestation in the Sierra de Lacandon National Park, Peten, Guatemala. The Professional Geographer 57(2), pp. 157-168.

CARR, D. L. (2008a): Migration to the Maya Biosphere Reserve, Guatemala: Why place matters. Human Organization, 67(1), pp. 37-48.

CARR, D. L. (2008b): Farm households and land use in a core conservation zone of the Maya Biosphere Reserve, Guatemala. Human Ecology, 36(2), pp. 1-12.

CARR, D. L., SUTER, L., BARBIERI, A. (2006): Population dynamics and tropical deforestation: State of the debate and conceptual challenges. Population and Environment, 27(1), pp. 89-113.

CARR, D. L., LOPEZ, A. C., BILSBORROW, R. E. (2009). The Population, agriculture, and environment nexus in Latin America: Country-level evidence from the latter half of the $20^{\text {th }}$ century. Population and Environment, 30, pp. 222-246.

CLARK, C. (1996): Seeking Legitimacy: The Story of Land Tenure in the Petén, Guatemala. Flores, Petén, Fulbright Foundation.

CONNELLY, T. W. (1994): Population pressure, labor availability, and agricultural disintensification: the decline of farming on Rusinga Island, Kenya. Human Ecology, 22(2), pp. 145-171.

DE SHERBININ, A., CARR, D. L., CASSELS, S., JANG, L. (2007): Population and natural resources. Annual Review of Environmental Economics, 32(5), pp. 1-29.

FEDER, ONCHAN (1987): Land Ownership Security and Farm Investment in Mainland Thailand American Journal of Agricultural Economics. 
GEERTZ, C. (1968): Agricultural Involution. Berkeley, University of California Press.

GOLDMAN, A. (1993): Agricultural innovation in three areas of Kenya: neo-Boserupian theories and regional characterization. Economic Geography 69(1), pp. 44-71.

KAIMOWITZ, D. (1995): Land Tenure, Land Markets, and Natural Resource Management by Large Landowners in the Petén and the Northern Transversal of Guatemala. Latin American Studies Association (LASA) Annual Meeting, Washington, D.C.

KRAUTKRAEMER, J. A. (1994): Population Growth, soil fertility, and agricultural intensification. The Journal of Development Economics 44(2), pp. 403-416.

NETTING, R., STONE, G. ET AL. (1993): Agricultural expansion, intensification, and market participation among the Kofyar, Jos Plateau, Nigeria. Population growth and agricultural change in Africa. B. L. Turner II, Goran, Hyden and R. W. Kates. Gainesville, Florida, University Press of Florida, pp. 206-249.

SCHELHAS, J. (1996): Land Use Choice and Change: Intensification and Diversification in the Lowland Tropics of Costa Rica. Human Organization 55(3), pp. 298-306.

SCHMINK, M., WOOD, C. (1993): Contested Frontiers. New York, N.Y., Columbia University Press.

SCHNEIDER, R. (1993): Land Abandonment, property rights, and agricultural sustainability in the Amazon. LATEN Dissemination note \#3 of The World Bank Latin American Technical Department Environmental Division.

SHRIAR, A. J. (2000): Agricultural intensity and its measurement in frontier regions. Agroforestry Systems 49(3), pp. 301-318.

SHRIAR, A. J. (2001): The Dynamics of Agricultural Intensification and Resource Conservation in the Buffer Zone of the Maya Biosphere Reserve, Peten, Guatemala. Human Ecology 29(1), pp. 27-48.

SUNDBERG, J. (1998): NGO Landscapes in the Maya Biosphere Reserve, Guatemala. Geographical Review 88(3), pp. 388-412.

TURNER II, B. L., ALI, S. (1996): Induced Intensification: Agricultural change in Bangladesh with implications for Malthus and Boserup. Proceeding of the National Academy of Sciences 93, pp. 14984-14991.

ZIMMERER, K. (1991): Wetland Production and smallholder persistence: Agricultural Change in a Highland Peruvian Region. Annals of the Association of American Geographers 81, pp. 443-463.

\section{Summary}

This paper used household survey data collected in the Maya Biosphere Reserve, Guatemala, to explore predictor variables associated with intensification on farm plots. Regression models demonstrate a correlation between high productivity of maize per hectare and smaller farm size, decreased subsistence level (more maize sold to market), and less percentage of the farm in crops. In sum, small farms with a small amount of land in crops devoting their crop for market sales are the most productive. This finding is consistent with theories of land and labor maximization. The results challenge the applicability of Boserupian theory to agricultural frontiers. Household size and length of time on the farm were insignificant predictors of maize production intensification. We believe that this is because land availability is too great and population density and labor and capital inputs are too low for population induced intensification. Future research would fruitfully pursue the question: At what threshold of population density is intensification inevitable?

Amy M. Lerner, David López-Carr University of California, Santa Barbara

Department of Geography 1832 Ellison Hall UC Santa Barbara

Santa Barbara, CA 93106-4060 e-mail:lerner@geog.ucsb.edu,carr@geog.ic.ucsb.edu 